\title{
Modulation by steroid hormones of a "sexy" acoustic signal in an Oscine species, the Common Canary Serinus canaria
}

\author{
FANNY RYBAK $^{1}$ and MANFRED GAHR ${ }^{2}$ \\ ${ }^{1}$ NAMC CNRS UMR 8620, Université Paris-Sud, Bât. 446, 91405 Orsay Cedex, France \\ ${ }^{2}$ Department of Developmental and Behavioural Biology, Vrije Universiteit Amsterdam, The Netherlands \\ Manuscript received on January 15, 2004; accepted for publication on February 5, 2004.
}

\begin{abstract}
The respective influence of testosterone and estradiol on the structure of the Common Canary Serinus canaria song was studied by experimentally controlling blood levels of steroid hormones in males and analyzing the consequent effects on acoustic parameters. A detailed acoustic analysis of the songs produced before and after hormonal manipulation revealed that testosterone and estradiol seem to control distinct song parameters independently. The presence of receptors for testosterone and estradiol in the brain neural pathway controlling song production strongly suggests that the observed effects are mediated by a steroid action at the neuronal level.
\end{abstract}

Key words: Oscines, Common Canary, song, steroid hormones.

\section{INTRODUCTION}

In vertebrates, steroid hormones produced by the gonads and circulating in the blood play a key role in modulating behaviors associated with reproduction. In the Common Canary Serinus canaria (hereafter called canary), song expression varies across seasons and is correlated with important variations in testosterone levels in the blood (Nottebohm et al. 1987, Leitner et al. 2001, 2002). The songs, produced by males, are composed of different syllables sequentially repeated in phrases. As in all other Oscine species, the production of song by the canary is controlled at the cerebral level by a network of interconnected brain nuclei: the so-called caudal motor pathway within the song control system (Nottebohm et al. 1976). This neural pathway is steroid sensitive: all the nuclei express receptors for androgens, e.g. testosterone, (Arnold et

Correspondence to: Fanny Rybak

E-mail: fanny.rybak@ibaic.u-psud.fr al. 1976, Brenowitz and Arnold 1992, Nastiuk and Clayton 1995, Gahr and Metzdorf 1997, Metzdorf et al. 1999) and the highest nucleus of the pathway - the HVC, which controls song organization (Yu and Margoliash 1996) - also contains receptors for estrogens, e.g. 17 $\beta$-estradiol (Gahr et al. 1993, Metzdorf et al. 1999). Furthermore, the production of estrogens in the brain is also important, as the enzyme aromatase, which converts androgens into estrogens, is expressed and is active in many brain areas, including one adjacent to the nucleus HVC (Schlinger and Arnold 1992a, b, Balthazart et al. 1996, Shen et al. 1995, Metzdorf et al. 1999).

\section{MATERIALS AND METHODS}

In order to assess how steroid hormones influence canary song structure and to determine whether testosterone has a direct effect on song parameters or an indirect effect via its estrogenic metabolite, we performed hormonal manipulations in sexually mature male canaries. We subcutaneously implanted 
either testosterone plus Fadrozole, an inhibitor of estradiol synthesis (group T + FAD) or testosterone plus a placebo (group $\mathrm{T}+\mathrm{Placebo}$ ) in 11 males, and compared the songs produced before and after implantation. After implantation, the song behavior was followed for three weeks.

\section{RESULTS}

For hormone measurements, blood samples were taken from the wing vein of all birds before and at several times after implantation. As expected, the levels of testosterone increased after implantation in animals of both groups and this increase was higher in the birds where conversion of testosterone into estradiol was inhibited, thus showing the efficiency of the experimental procedure.

A detailed acoustic analysis performed on song structure revealed that some parameters that we studied were not sensitive to steroid hormones, but others appeared to be testosterone-dependent, estradiol-dependent or both. We did not observe modifications of the repertoire size (total number of different syllables produced by one individual) or the repertoire composition. The mean duration of the songs was not affected by the hormonal treatment, but three song parameters were significantly modified (Fig. 1). First, the duration of phrases was increased in both groups. Second, the number of different phrases per song decreased significantly in both groups of birds, with this effect significantly higher for the birds having both testosterone and estradiol available $(\mathrm{T}+$ Placebo). Finally, the rate of production of syllables along sequences was higher in $\mathrm{T}+$ Placebo birds, whereas this parameter was not changed in $\mathrm{T}+\mathrm{FAD}$ birds.

\section{DISCUSSION}

We have shown that steroid hormones influence song structure in canaries and that testosterone and estradiol seem to control distinct song parameters independently. We cannot reject the possibility that testosterone acts indirectly on the song system (i.e. transsynaptically) via, for example, the control of the catecholaminergic innervation of the song

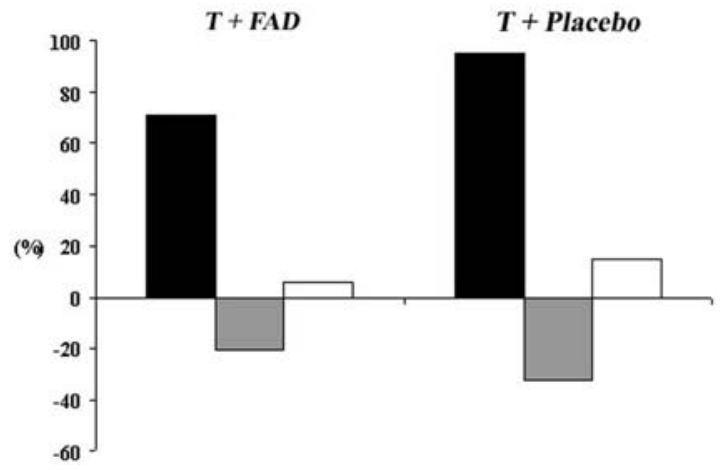

Fig. 1 - Changes (in \%) in 3 song parameters after hormonal manipulation in the two groups of birds. The song parameters are: duration of phrases (black bars), number of different phrases per song (gray bars), and rate of production of syllables along sequences (white bars). The zero level refers to mean values obtained for these song parameters before hormonal manipulation.

system, as has been shown recently (Appeltants et al. 2003). However, the presence of receptors for testosterone and estradiol in the brain neural pathway that controls song production, especially in nucleus HVC, strongly suggests that the observed effects were mediated by a direct steroid action at the neuronal level. Furthermore, blocking the production of estrogens during testosterone-induced song development in adult female canaries also alters song patterns, and these effects are correlated with the inhibition of expression of estrogen-sensitive genes in HVC (Fusani et al. 2002).

\section{CONCLUSION}

In canaries, the song produced by males is involved in both inter-sexual and intra-sexual relationships. Females of this species are especially responsive to certain song parameters, including the repetition rate of syllables (Vallet and Kreutzer 1995, Drãgãnoiu et al. 2002), which is estradiol-dependent, as we have shown here. Therefore, it is possible that females rely on this parameter in the male songs to estimate the physiological state of their potential sexual partners. Further investigations are needed to determine the behavioral significance of other song parameters that we have shown to be under the control of steroid hormones. 


\section{RESUMO}

A influência da testosterona e do estradiol, respectivamente, na estrutura do canto do Canário-do-reino Serinus canaria foi estudada analisando o efeito da manipulação dos níveis sanguíneos de hormônios esteróides em machos nos parâmetros acústicos do canto. Uma analise detalhada dos cantos produzidos antes e depois da manipulação hormonal revelou que testosterona e estradiol parecem controlar independentemente parâmetros acústicos distintos. A presença de receptores para esses hormônios no circuito neuronal para controle da produção do canto sugere fortemente que os efeitos observados são mediados pela ação de esteróides a nivel neuronal.

Palavras-chave: pássaros canoros, Canário-do-reino, canto, hormônios esteróides.

\section{REFERENCES}

Appeltants D, Ball GF and Balthazart J. 2003. Song activation by testosterone is associated with an increased catecholaminergic innervation of the song control system in female canaries. Neuroscience 121: 801-814.

Arnold AP, Nottebohm F And Pfaff DW. 1976. Hormone concentrating cells in vocal control and other areas of the brain of the Zebra Finch (Poephila guttata). J Comp Neurol 165: 487-512.

Balthazart J, Tlemcani O and Ball F. 1996. Do sex differences in the brain explain sex differences in the hormonal induction of reproductive behavior? What 25 years of research on the Japanese Quail tell us. Horm Behav 30: 627-661.

Brenowitz EA And Arnold AP. 1992. Hormone accumulation in song regions of the canary brain. $\mathrm{J}$ Neurobiol 23: 81-85.

Drãgãnoiu TI, Nagle L and Kreutzer M. 2002. Directional female preference for an exaggerated male trait in Canary (Serinus canaria) song. Proc Roy Soc London B 269: 2525-2531.

Fusani L, Metzdorf R, Hutchinson JB And Gahr M. 2002. Aromatase inhibition affects testosteroneinduced masculinization of song and the neural song system in female canaries. J Neurobiol 54: 370-379.

Gahr M and Metzdorf R. 1997. Distribution and dynamics in the expression of androgen and estrogen receptors in vocal control systems of songbirds. Brain Res Bull 44: 509-517.
GAHr M, GÜtTINGer HR AND Kroodsma DE. 1993. Estrogen receptors in the avian brain: survey reveals general distribution and forebrain areas unique to songbirds. J Comp Neurol 327: 112-122.

Leitner S, Voigt C, Garcia-Segura T, Van't Hof T AND GAHr M. 2001. Seasonal activation and inactivation of song motor memories in wild canaries is not reflected in neuroanatomical changes of forebrain song areas. Horm Behav 40: 160-168.

Leitner S, Voigt C and Gahr M. 2002. Seasonal changes in the song pattern of the non-domesticated Island Canary (Serinus canaria), a field study. Behaviour 138: 885-904.

Metzdorf R, Gahr M and Fusani L. 1999. Distribution of aromatase, estrogen receptor, and androgen receptor mRNA in the forebrain of songbirds and non songbirds. J Comp Neurol 407: 115-129.

Nastiuk KL and Clayton DF. 1995. The canary androgen receptor mRNA is localized in the song control nuclei of the brain and is rapidly regulated by testosterone. J Neurobiol 26: 213-224.

NotTebohm F, Stokes TM and Leonard CM. 1976. Central control of song in the Canary, Serinus canaria. J Comp Neurol 165: 457-486.

NotTebohm F, NotTebohm ME, Crane LA And WingFIELD JC. 1987. Seasonal changes in gonadal hormone levels of adult male canaries and their relation to song. Behav Neural Biol 47: 197-211.

Schlinger BA AND Arnold AP. 1992a. Plasma sex steroids and tissue aromatization in hatchling Zebra Finches: implications for the sexual differentiation of singing behavior. Endocrinology 130: 289-299.

Schlinger BA AND Arnold AP. 1992b. Circulating estrogens in a male songbird originate in the brain. Proc Natl Acad Sci 89: 7650-7653.

Shen P, Schlinger BA, CAmpagnoni AT and Arnold AP. 1995. An atlas of aromatase m RNA expression in the Zebra Finch brain. J Comp Neurol 360: 172184.

Vallet E and Kreutzer M. 1995. Female canaries are sexually responsive to special song phrases. Anim Behav 49: 1603-1610.

Yu AC and Margoliash D. 1996. Temporal hierarchical control of singing in birds. Science 273: 1871-1875. 